\title{
Comparison of ondansetron and tropisetron in preventing postoperative nausea and vomiting
}

\author{
A meta-analysis of randomized controlled trials
}

Rui Wang, MS, Xuesong Song, MD, PhD, Yan Chen, MD, Na Wang, MD, PhD, Jinguo Wang, MD, PhD.

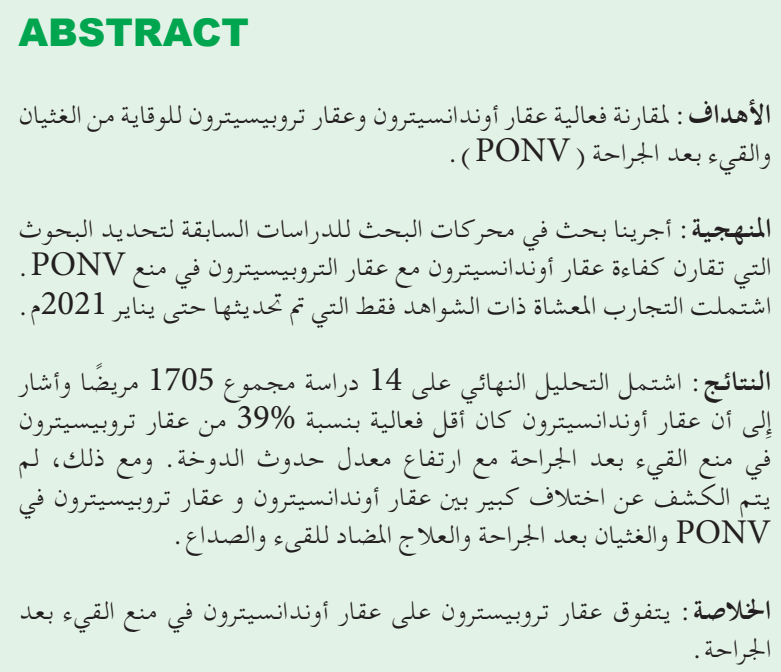

Objectives: To compare the efficacy of prophylactic ondansetron and tropisetron for postoperative nausea and vomiting (PONV).

Methods: A literature search was performed to identify studies that compare the efficiency of ondansetron with that of tropisetron in preventing PONV. Only randomized controlled trials updated to January, 2021 were included.

Results: The final pooled analysis included 14 studies totaling 1705 patients and indicated that ondansetron was 39\% less effective than tropisetron in preventing postoperative vomiting with a higher incidence of dizziness. However, no significant difference was detected between ondansetron and tropisetron in PONV, postoperative nausea, antiemetic treatment, and headache.

Conclusions: Tropisetron is superior to ondansetron in preventing postoperative vomiting.

PROSPERO No: CRD42021237368

Keywords: meta-analysis, ondansetron, tropisetron, postoperative, antiemetic
Saudi Med J 2021; Vol. 42 (7): 707-713

doi: 10.15537/smj.2021.42.7.20210135

From the Department of Computer Network (Wang R), Technology School, Jilin Business and Technology College, Changchun, Jilin; from the Department of Anesthesiology (Song, Chen, Wang N); and from the Department of Urology (Wang J), The First Hospital of Jilin University, Changchun, China.

Received 18th March 2021. Accepted 31st May 2021.

Address correspondence and reprint request to: Dr. Jinguo Wang, Department of Urology, The First Hospital of Jilin University, Changchun, China.E-mail: jinguo@jlu.edu.cn

ORCID ID: http://orcid.org/0000-0001-9794-9789

$\mathrm{P}$ ostoperative nausea and vomiting (PONV) is a distressing side effect after anesthesia, ${ }^{1}$ because it may cause some adverse effects such as deprivation of body fluids, electrolyte imbalance, delayed recovery, aspiration pneumonia, and decreased satisfaction of patients' after surgery. ${ }^{2}$

Prophylactic

administration

of 5-hydroxytryptamine-3 (5-HT3) receptor antagonists has been utilized as an effective method for preventing PONV. Comparative studies between different 5-HT3 antagonists for preventing PONV failed to show a clear advantage of a specific 5-HT3 antagonist. ${ }^{3}$

This meta-analysis was designed to determine the effect of two 5-HT3 receptor antagonists with different half-lives in preventing PONV, that is, the shortacting ondansetron versus the relatively long-acting tropisetron.

Methods. Two investigators (NW, RW) identified the eligible studies by searching PubMed, Web of Science, Cochrane Library, and Google Scholar, using "prevention," "nausea," "vomiting," "ondansetron," and

Disclosure. Authors have no conflict of interests, and the work was not supported or funded by any drug company. 
"tropisetron" as search terms updated to January, 2021. Potential randomized controlled trials (RCTs) were identified by a systematic search of reference lists from related articles.

Inclusion criteria were: a RCT study; patients should have undergone operation; records of PONV-data; ondansetron or tropisetron administered prophylactically; and ondansetron and tropisetron comparison. On the other hand, none-english articles, animal studies, children studies, and published abstracts, meeting papers and letters were excluded.

The quality of the RCTs was separately evaluated by 2 investigators (JW, XS) utilizing the Cochrane Collaboration guidelines and Jadad improvement score. ${ }^{4,5}$ Studies with Jadad improvement score of less than 4 were excluded.

Two independent investigators (YC, RW) extracted relevant data from the included studies. The primary outcome was PONV, while additional outcomes included the requirement of antiemetic treatment and the related complications. Any disagreement was solved by a third investigator.

Statistical analysis. Statistical calculations were conducted using Revman 5.3 (Cochrane Collaboration). The outcome was displayed as odds ratio (OR) with 95\% confidence interval (CI). $\mathrm{I}^{2}$ value was utilized to evaluate heterogeneity. If $\mathrm{I}^{2} \leq 50 \%$, a fixed-effect model was peformed. Funnel plot and Egger test were utilized to assess publication bias. Statistical significance was $p<0.05$.

Results. The literature search identified 68 articles initially. After reading the abstracts, 42 studies were excluded. Of the 26 remaining studies, 14 articles were included in this meta-analysis after reviewing the full manuscript (Figure 1). ${ }^{6-19}$ The characteristics of the 14 articles involving 1705 patients are summarized in Table 1. An overview of the risk of bias was shown in Figure 2.

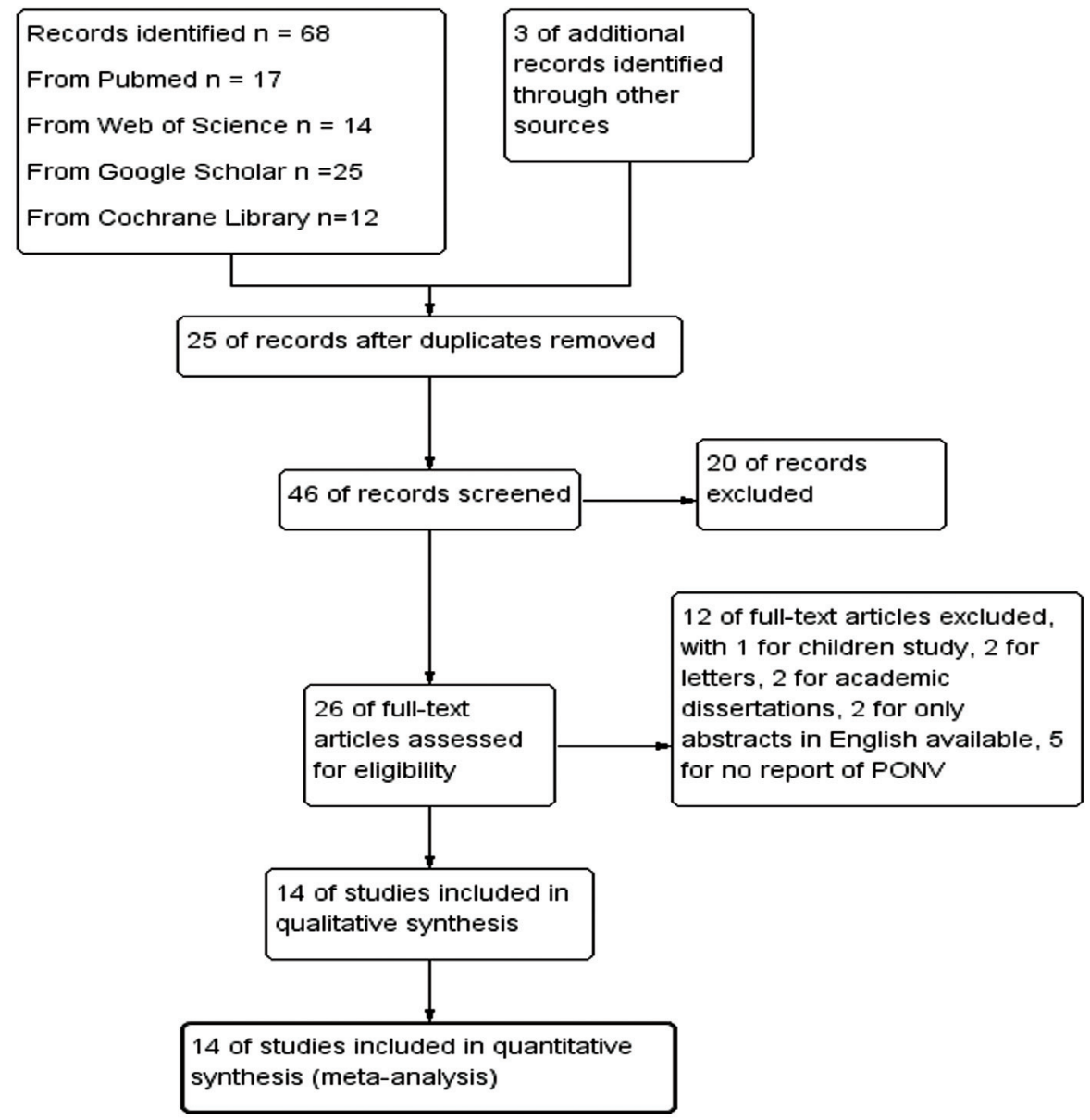

Figure 1 - Flow diagram of literature search. 
Table 1 - Characteristics of the included studies.

\begin{tabular}{|c|c|c|c|c|c|c|c|c|}
\hline $\begin{array}{l}\text { Author/ } \\
\text { year }\end{array}$ & Dosage & $\begin{array}{c}\text { Jadad } \\
\text { improvement } \\
\text { score }\end{array}$ & $\begin{array}{l}\text { Sample } \\
\text { size } \\
\mathrm{O} / \mathrm{T} \\
\end{array}$ & $\begin{array}{l}\text { Patient characteristics/ } \\
\text { surgical setting }\end{array}$ & $\begin{array}{l}\text { Administration } \\
\text { time }\end{array}$ & $\begin{array}{c}\text { PONV } \\
\text { measurement } \\
\text { tool }\end{array}$ & $\begin{array}{l}\text { Observing } \\
\text { time } \\
\text { (hours) }\end{array}$ & $\begin{array}{c}\text { Outcomes } \\
\text { measures }\end{array}$ \\
\hline $\begin{array}{l}\text { Aydin et } \mathrm{al}^{6} \\
2019\end{array}$ & $\begin{array}{l}\text { Ondansetron } \\
8 \mathrm{mg} ; \\
\text { Tropisetron } \\
5 \mathrm{mg}\end{array}$ & 7 & $55 / 55$ & $\begin{array}{l}\text { 18-65 years, ASA: I-II; } \\
\text { Middle ear surgery; } \\
\text { General anesthesia }\end{array}$ & $\begin{array}{l}\text { During skin } \\
\text { closure }\end{array}$ & $\begin{array}{l}\text { Visual analog } \\
\text { score } 0-3\end{array}$ & 48 & $\mathrm{a}, \mathrm{b}, \mathrm{c}, \mathrm{d}, \mathrm{e}$ \\
\hline $\begin{array}{l}\text { Jokela et } \mathrm{al}^{7} \\
2002\end{array}$ & $\begin{array}{l}\text { Ondansetron } \\
16 \mathrm{mg} \\
\text { Tropisetron } \\
\quad 5 \mathrm{mg}\end{array}$ & 7 & $60 / 60$ & $\begin{array}{c}\text { O: } 51 \pm 13 \text { years; } \\
\text { T: } 49 \pm 14 \text { years; } \\
\text { ASA: I-III; female; } \\
\text { Thyroid or parathyroid surgery; } \\
\text { General anesthesia }\end{array}$ & $\begin{array}{l}\text { Orally } 1 \text { hour } \\
\text { before the } \\
\text { operation }\end{array}$ & Yes or no & 24 & $\begin{array}{l}\mathrm{a}, \mathrm{b}, \mathrm{c}, \mathrm{d} \\
\quad \mathrm{e}, \mathrm{f}\end{array}$ \\
\hline $\begin{array}{l}\text { Quan et } \mathrm{a}^{8} \\
2007\end{array}$ & $\begin{array}{l}\text { Ondansetron } \\
\quad 4 \mathrm{mg} ; \\
\text { Tropisetron } \\
5 \mathrm{mg}\end{array}$ & 5 & $120 / 118$ & $\begin{array}{l}\text { 18-75 years, ASA: I-II; } \\
\text { Elective surgery }\end{array}$ & $\begin{array}{l}\text { Before } \\
\text { induction of } \\
\text { anesthesia }\end{array}$ & Yes or no & 24 & $a, b, c$ \\
\hline $\begin{array}{l}\text { Ekinci et al } \\
2011\end{array}$ & $\begin{array}{l}\text { Ondansetron } \\
4 \mathrm{mg} ; \\
\text { Tropisetron } \\
2.5 \mathrm{mg}\end{array}$ & 7 & $20 / 20$ & $\begin{array}{c}20-72 \text { years, ASA: I-II; female; } \\
\text { Total abdominal hysterectomy } \\
\text { General Anesthesia }\end{array}$ & $\begin{array}{l}5 \text { min after } \\
\text { induction of } \\
\text { anesthesia }\end{array}$ & $\begin{array}{l}\text { Visual analog } \\
\text { score } 0-3\end{array}$ & 24 & $a, d, e, f$ \\
\hline $\begin{array}{l}\text { Sarvela et } \mathrm{al}^{10} \\
2006\end{array}$ & $\begin{array}{l}\text { Ondansetron } \\
8 \mathrm{mg} \\
\text { Tropisetron } \\
5 \mathrm{mg}\end{array}$ & 5 & $30 / 28$ & $\begin{array}{l}33 \pm 5 \text { years; female; } \\
\text { Elective cesarean section; } \\
\text { Spinal-epidural anesthesia }\end{array}$ & $\begin{array}{l}5 \text { min after } \\
\text { delivery }\end{array}$ & $\begin{array}{c}\text { Numerical rating } \\
\text { score } \\
0-10 \\
>3\end{array}$ & 24 & a, d \\
\hline $\begin{array}{l}\text { Scholz et a }{ }^{11} \\
1998\end{array}$ & $\begin{array}{l}\text { Ondansetron } \\
4 \mathrm{mg} ; \\
\text { Tropisetron } \\
2 \mathrm{mg}\end{array}$ & 6 & $271 / 296$ & $\begin{array}{l}\text { 18-75 years, ASA: I-III; } \\
\text { abdominal and non-abdominal } \\
\text { (ENT, eye, breast) surgery } \\
\text { General anesthesia }\end{array}$ & $\begin{array}{l}3 \text { min before } \\
\text { induction of } \\
\text { anesthesia }\end{array}$ & Yes or no & 24 & $\mathrm{a}, \mathrm{d}, \mathrm{e}$ \\
\hline $\begin{array}{l}\text { Naguib et al }{ }^{12} \\
1996\end{array}$ & $\begin{array}{l}\text { Ondansetron } \\
\quad 4 \mathrm{mg} ; \\
\text { Tropisetron } \\
5 \mathrm{mg}\end{array}$ & 5 & $29 / 25$ & $\begin{array}{c}\text { 21-68 years, ASA: I-II; } \\
\text { Elective laparoscopic } \\
\text { cholecystectomy; } \\
\text { General anesthesia }\end{array}$ & $\begin{array}{l}10 \text { min before } \\
\text { induction of } \\
\text { anesthesia }\end{array}$ & Yes or no & 24 & a \\
\hline $\begin{array}{l}\text { Koivuranta et } \\
\text { al }^{13} 1999\end{array}$ & $\begin{array}{l}\text { Ondansetron } \\
8 \mathrm{mg} ; \\
\text { Tropisetron } \\
5 \mathrm{mg}\end{array}$ & 6 & $45 / 43$ & $\begin{array}{l}\geq 18 \text { years; ASA: I-III; } \\
\text { Gynecological laparotomy; } \\
\text { General anesthesia }\end{array}$ & $\begin{array}{l}\text { At the end of } \\
\text { surgery }\end{array}$ & $\begin{array}{l}\text { Visual analog } \\
\text { score } 0-3\end{array}$ & 24 & $\begin{array}{l}a, b, c, d, \\
\quad e, f\end{array}$ \\
\hline $\begin{array}{l}\text { Wang et } \mathrm{al}^{14} \\
2002\end{array}$ & $\begin{array}{l}\text { Ondansetron } \\
\text { 8mg; } \\
\text { Tropisetron } \\
\text { 3mg }\end{array}$ & 4 & $30 / 30$ & $\begin{array}{c}\text { No mention } \\
\text { Elective surgery; } \\
\text { General anesthesia }\end{array}$ & $\begin{array}{l}\text { At the end of } \\
\text { surgery }\end{array}$ & $\begin{array}{l}\text { Visual analog } \\
\text { score } 0-3\end{array}$ & 24 & a, d \\
\hline $\begin{array}{l}\text { Wei et a }{ }^{15} \\
1999\end{array}$ & $\begin{array}{l}\text { Ondansetron } \\
\quad 4 \mathrm{mg} ; \\
\text { Tropisetron } \\
5 \mathrm{mg}\end{array}$ & 4 & $30 / 30$ & $\begin{array}{l}\text { 21-72 years, ASA: I-II; } \\
\text { Elective abdominal surgery; } \\
\text { General anesthesia }\end{array}$ & $\begin{array}{l}10 \text { min before } \\
\text { induction of } \\
\text { anesthesia }\end{array}$ & $\begin{array}{l}\text { Visual analog } \\
\text { score } 0-3\end{array}$ & 24 & $\mathrm{a}, \mathrm{c}$ \\
\hline $\begin{array}{l}\text { Paech et } \mathrm{al}^{16} \\
2003\end{array}$ & $\begin{array}{l}\text { Ondansetron } \\
\quad 4 \mathrm{mg} ; \\
\text { Tropisetron } \\
2 \mathrm{mg}\end{array}$ & 7 & $36 / 42$ & $\begin{array}{c}\text { O: } 48.3 \pm 12.2 \text { years; } \\
\text { T: } 49.4 \pm 14.1 \text { years; } \\
\text { female; } \\
\text { Major open abdominal } \\
\text { gynecological surgery } \\
\text { General anesthesia combined } \\
\text { with epidural anesthesia }\end{array}$ & $\begin{array}{l}\text { After induction } \\
\text { of anesthesia }\end{array}$ & $\begin{array}{l}\text { Visual analog } \\
\text { score } 0-3\end{array}$ & 24 & $\mathrm{~b}, \mathrm{c}, \mathrm{d}$ \\
\hline $\begin{array}{l}\text { Tsui et a } \mathbf{l}^{17} \\
1999\end{array}$ & $\begin{array}{l}\text { Ondansetron } \\
4 \mathrm{mg} ; \\
\text { Tropisetron } \\
5 \mathrm{mg}\end{array}$ & 6 & $39 / 37$ & $\begin{array}{c}\leq 65 \text { years; ASA: I-III; female; } \\
\text { Gynecological laparotomy } \\
\text { General anesthesia }\end{array}$ & $\begin{array}{l}\text { Immediately } \\
\text { before induction } \\
\text { of anesthesia }\end{array}$ & $\begin{array}{l}\text { Visual analog } \\
\text { score } 0-3\end{array}$ & 24 & $\mathrm{~b}, \mathrm{c}, \mathrm{d}$ \\
\hline $\begin{array}{l}\text { Geng et al }{ }^{18} \\
2009\end{array}$ & $\begin{array}{l}\text { Ondansetron } \\
\text { 8mg; } \\
\text { Tropisetron } \\
\text { 5mg }\end{array}$ & 4 & $48 / 48$ & $\begin{array}{l}\text { 18-60 years, ASA: I-II; female; } \\
\text { Gynecological laparotomy; } \\
\text { General anesthesia }\end{array}$ & $\begin{array}{l}30 \text { min before } \\
\text { completion of } \\
\text { surgery }\end{array}$ & Yes or no & 24 & $b, c, d, f$ \\
\hline $\begin{array}{l}\text { Argiriadou } \\
\text { et } \mathrm{al}^{19} 2002\end{array}$ & $\begin{array}{l}\text { Ondansetron } \\
4 \mathrm{mg} ; \\
\text { Tropisetron } \\
5 \mathrm{mg}\end{array}$ & 7 & $29 / 31$ & $\begin{array}{c}\text { O: } 43.9 \pm 13.6 \text { years; } \\
\text { T: } 47.9 \pm 16.7 \text { years; } \\
\text { ASA: I-II; } \\
\text { Elective laparoscopic } \\
\text { cholecystectomy; } \\
\text { General anesthesia }\end{array}$ & $\begin{array}{l}\text { At anesthesia } \\
\text { induction }\end{array}$ & $\begin{array}{l}\text { Visual analog } \\
\text { score } 0-5\end{array}$ & 12 & $\mathrm{c}, \mathrm{d}, \mathrm{e}$ \\
\hline
\end{tabular}

RCT: randomized controlled trial, ASA: American Society of Anesthesiologists, PONV: postoperative nausea and vomiting,

O: Ondansetron, T: Tropisetron, a: The incidence of PONV, b: The incidence of PON, c: The incidence of POV, d: The incidence of antiemetic treatment, e: The incidence of headache, $\mathrm{f}$ : The incidence of dizziness 


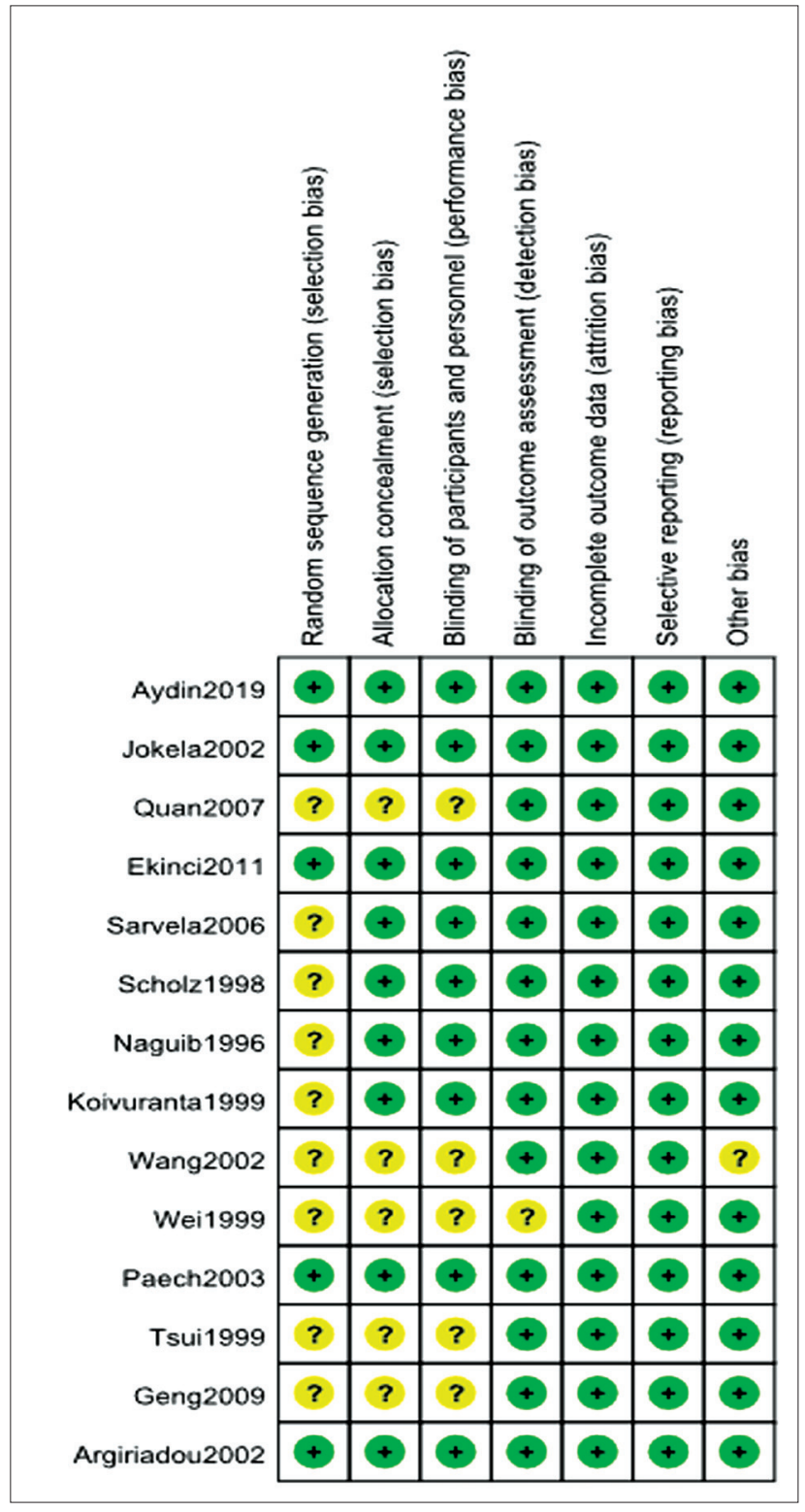

Figure 2 - Risk of bias summary.

As shown in Figure 3, 10 studies involving 1395 patients reported the incidence of PONV. The effect of ondansetron and tropisetron was equal in preventing PONV (OR: $1.02 ; 95 \%$ CI: 0.82-1.28; $p=0.84$; $\mathrm{I}^{2}=25 \%$ ) (Figure 3A). ${ }^{6-15}$

Postoperative nausea (PON) was assessed in 7 studies including 806 patients. ${ }^{6-8,16-18}$ Meanwhile, postoperative vomiting (POV) was reported in 9 studies including

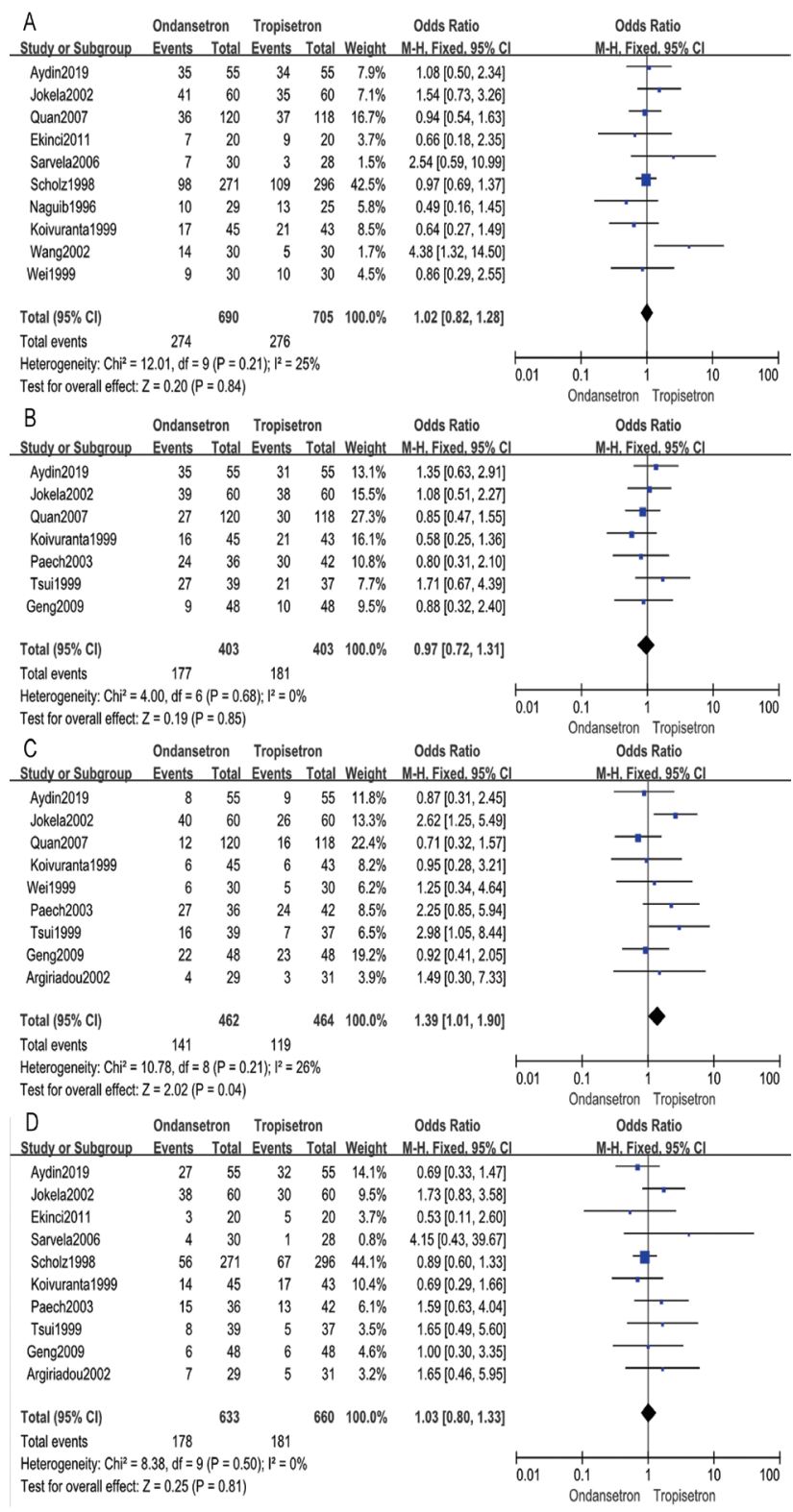

Figure 3 - Forest plot comparing between ondansetron and tropisetron: A) postoperative nausea and vomiting; B) postoperative nausea; C) postoperative vomiting; D) antiemetic treatment.

926 patients. ${ }^{6-8,13,15-19}$ This meta-analysis indicated no difference in PON between ondansetron and tropisetron (OR: 0.97; 95\% CI: 0.72-1.31; $p=0.85$; $\mathrm{I}^{2}=0 \%$ ) (Figure 3B). Ondansetron was 39\% less effective than tropisetron in preventing POV (OR: 1.39; $95 \%$ CI: 1.01-1.90; $p=0.04 ; \mathrm{I}^{2}=26 \%$ ) (Figure 3C).

Antiemetic treatment. Antiemetic treatment was reported in 10 studies including 1293 


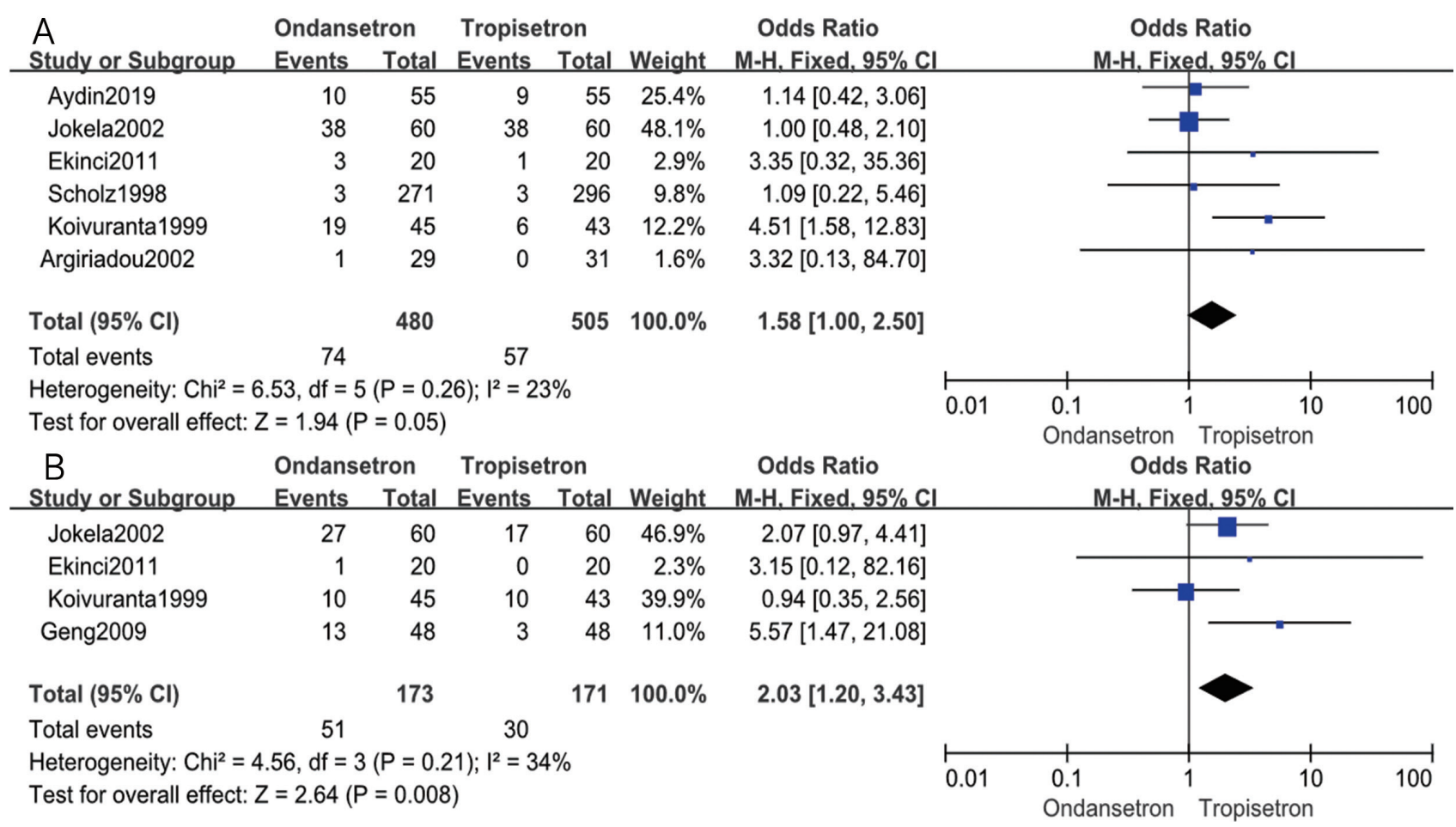

Figure 4 - Forest plot of comparison of the side effects experienced by patients receiving ondansetron and tropisetron treatment: A) headache and B) dizziness.

patients. ${ }^{6,7,9-11,13,16-19}$ The difference in antiemetic treatment was not statistically significant between ondansetron and tropisetron (OR: $1.03 ; 95 \% \mathrm{CI}$ : 0.80-1.33; $p=0.81 ; \mathrm{I}^{2}=0 \%$ ) (Figure 3D).

Complications. Headache was evaluated in 6 studies involving 985 patients. ${ }^{6,7,9,11,13,19}$ As displayed in Figure $4 \mathrm{~A}$, ondansetron compared to tropisetron tended to have higher incidence of headache; however, it wasn't statistically significant (OR: 1.58; 95\% CI: 1.00-2.50; $\left.p=0.05 ; \mathrm{I}^{2}=23 \%\right)$. On the other hand, dizziness was evaluated in 4 studies involving 344 patients. $7,9,13,18$ As shown in Figure 4B, ondansetron had 103\% higher incidence of dizziness than that with tropisetron (OR: 2.03; 95\% CI: $1.20-3.43 ; p=0.008 ; \mathrm{I}^{2}=34 \%$ ).

Publication bias. The funnel plot of PONV was asymmetrical. However, Egger test did not reveal significant difference in PONV $(p=0.501)$.

Discussion. Previous systematic review has shown that 5-HT3 receptor antagonists could prevent PONV. ${ }^{20}$ The mechanism may be that they can block vagal nerves which trigger the emetic reflex. ${ }^{21}$ Ondansetron is the original member of this class with a short elimination half-life, and its effect is confirmed in many studies of different patient populations. Tropisetron is also a potent 5-HT3 receptor antagonist with longer elimination half-life than that of ondansetron. It is produced by systematic methyl substitution of the serotonin molecules. ${ }^{22}$ It is still a matter of significant interest to compare the efficacy and side-effect profiles of the short-acting ondansetron and the relatively long-acting tropisetron prophylactically given to patients of both genders undergoing surgery.

The present meta-analysis indicated that tropisetron was more effective than ondansetron in preventing POV, and prophylactic ondansetron and tropisetron had similar incidence of PONV, incidence of PON, and antiemetic efficacy in adults.

We note a difference in the half-life time of ondansetron (T1/2 = 3.2 hours) and tropisetron (T1/2 $=7.3-8$ hours), which is probably related to the lower percentage of patients who experienced POV in the tropisetron group. ${ }^{23}$ It indicates that prophylactic tropisetron can provide a more long-standing antiemetic coverage after surgery. However, tropisetron does not reduce the incidence of PONV and PON, and 
requirement for antiemetic treatment, as compared to that with ondansetron.

Furthermore, tropisetron causes fewer side effects than ondansetron. Compared with ondansetron, tropisetron can decrease the incidence of dizziness. Additionally, tropisetron tends to increase the incidence of headache; however, this difference was not statistically significant. If more RCTs are included and more patients are involved, tropisetron may be shown to be more effective. Nonetheless, we were able to demonstrate in this meta-analysis that tropisetron can more effectively prevent POV with a lower incidence of dizziness than ondansetron.

Several potential limitations associated with these results should be mentioned. First, 2 of the included RCTs had relatively small sample sizes, which might influence the credibility of the conclusion. Second, there were some clinical differences between the included studies: dosages and the administration routes of the study drugs in the included RCTs vary, which may affect the reliability of pooling effects. Finally, the optimal dosages of ondansetron and tropisetron were the remaining question, which need further attention.

In conclusion, tropisetron is superior to ondansetron in preventing POV. It is 39\% more effective than ondansetron in preventing POV with a lower incidence of dizziness.

Acknowledgment. We would like to thank Editage (www.editage.cn) for English language editing.

\section{References}

1. Kovac AL. Updates in the management of postoperative nausea and vomiting. Adv Anesth 2018; 36: 81-97.

2. Matsuura $H$, Inoue $S$, Kawaguchi M. The risk of postoperative nausea and vomiting between surgical patients received propofol and sevoflurane anesthesia: a matched study. Acta Anaesthesiol Taiwan 2016; 54: 114-120.

3. Yokoi A, Mihara T, Ka K, Goto T. Comparative efficacy of ramosetron and ondansetron in preventing postoperative nausea and vomiting: an updated systematic review and meta-analysis with trial sequential analysis. PLoS One 2017; 12: e0186006.

4. Higgins JP, Altman DG, Gøtzsche PC, Jüni P, Moher D, Oxman AD, et al. The Cochrane Collaboration. BMJ 2011; 343: d5928.

5. Jadad AR, Moore RA, Carroll D, Jenkinson C, Reynolds DJ, Gavaghan DJ, et al. Assessing the quality of reports on randomized clinical trials: is blinding necessary? Controlled Clinical Trials 1996; 17: 1-12.

6. Aydin A, Kaçmaz M, Boyaci A. Comparison of ondansetron, tropisetron, and palonosetron for the prevention of postoperative nausea and vomiting after middle ear surgery. Curr Ther Res Clin Exp 2019; 91: 17-21.
7. Jokela R, Koivuranta M, Kangas-Saarela T, Purhonen S, Alahuhta S. Oral ondansetron, tropisetron or metoclopramide to prevent postoperative nausea and vomiting: a comparison in high-risk patients undergoing thyroid or parathyroid surgery. Acta Anaesthesiol Scand 2002; 46: 519-524.

8. Quan X, Ye TH, Zhu B. [A randomized double-blind study of prevention of postoperative nausea and vomiting with ondansetron, tropisetron, or granisetron in patients undergoing general anesthesia]. Zhongguo Yi Xue Ke Xue Yuan Xue Bao 2007; 29: 107-110. Chinese

9. Ekinci O, Malat I, Işıtmangil G, Aydın N. A randomized comparison of droperidol, metoclopramide, tropisetron, and ondansetron for the prevention of postoperative nausea and vomiting. Gynecol Obstet Invest 2011; 71: 59-65.

10. Sarvela PJ, Halonen PM, Soikkeli AI, Kainu JP, Korttila KT. Ondansetron and tropisetron do not prevent intraspinal morphine and fentanyl induced pruritus in elective cesarean delivery. Acta Anaesthesiol Scand 2006; 50: 239-244.

11. Scholz J, Hennes HJ, Steinfath M, Färber L, Schweiger C, Dick $\mathrm{W}$, et al. Tropisetron or ondansetron compared with placebo for prevention of postoperative nausea and vomiting. Eur $J$ Anaesthesiol 1998; 15: 676-685.

12. Naguib M, el Bakry AK, Khoshim MH, Channa AB, el Gammal M, el Gammal K, et al. Prophylactic antiemetic therapy with ondansetron, tropisetron, granisetron and metoclopramide in patients undergoing laparoscopic cholecystectomy: a randomized, double-blind comparison with placebo. Can J Anaesth 1996; 43: 226-231.

13. Koivuranta M, Ala-Kokko TI, Jokela R, Ranta P. Comparison of ondansetron and tropisetron combined with droperidol for the prevention of emesis in women with a history of post-operative nausea and vomiting. Eur J Anaesthesiol 1999; 16: 390-395.

14. Wang C, Xu N, Xiong LZ, Liu HF, Yang XY, Lu ZH, et al. [Dexamethasone enhances the effect of tropisetron and ondansetron against nausea and vomiting against nausea and vomiting after patient-controlled analgesia]. Di Yi Jun Yi Da Xue Xue Bao 2002; 22: 159-161. Chinese.

15. Zhao W, Li C, Jia N. Prevention of postoperative nausea and vomiting with tropisetron or ondansetron in patients undergoing general anesthesia. Journal of China-Japan Friendship Hospital 1999; 13: 154-156.

16. Paech MJ, Rucklidge MWM, Banks SL, Gurrin LC, Orlikowski CEP, Pavy TJG. The efficacy and cost-effectiveness of prophylactic 5-hydroxytryptamine3 receptor antagonists: Tropisetron, Ondansetron and Dolasetron. Anaesth Intensive Care 2003; 31: 11-17.

17. Tsui SL, Ng KF, Wong LC, Tang GW, Pun TC, Yang JC. Prevention of postoperative nausea and vomiting in gynaecological laparotomies: a comparison of tropisetron and ondansetron. Anaesth Intensive Care 1999; 27: 471-476.

18. Geng ZY, Wang DX, Liu YH. Prevention of postoperative nausea and vomiting in patients undergoing gynecological laparoscopy: a comparison of tropisetron and ondansetron. Chinese Journal of New Drugs 2009; 18: 2316-2319.

19. Argiriadou H, Papaziogas B, Pavlidis T, Parlapani A, Georgiou M, Papagiannopoulou P, et al. Tropisetron vs ondansetron for prevention of postoperative nausea and vomiting after laparoscopic cholecystectomy: a randomized double-blind, placebo-controlled study. Surg Endosc 2002; 16: 1087-1090. 
20. Sridharan K, Sivaramakrishnan G. Drugs for preventing post-operative nausea and vomiting in patients undergoing laparoscopic cholecystectomy: Network meta-analysis of randomized clinical trials and trial sequential analysis. Int J Surg 2019; 69: 1-12.

21. Juza R, Vlcek P, Mezeiova E, Musilek K, Soukup O, Korabecny J. Recent advances with 5-HT(3) modulators for neuropsychiatric and gastrointestinal disorders. Med Res Rev 2020; 40: 1593-1678.
22. Yang Y, Zhang L. A narrative review of tropisetron and palonosetron for the control of chemotherapy-induced nausea and vomiting. Chin Clin Oncol 2020; 9: 17.

23. Bell GC, Caudle KE, Whirl-Carrillo M, Gordon RJ, Hikino $\mathrm{K}$, Prows $\mathrm{CA}$, et al. Clinical Pharmacogenetics Implementation Consortium (CPIC) guideline for CYP2D6 genotype and use of ondansetron and tropisetron. Clin Pharmacol Ther. 2017; 102: $213-218$. 